\title{
VSEIR Mathematical Model on Anthrax Disease Dissemination in Animal Population with Vaccination and Treatment Effects
}

\section{Model Matematika VSEIR Penyebaran Penyakit Antraks pada Populasi Hewan dengan Efek Vaksinasi dan Pengobatan}

\author{
Nurfitria Prawandani ${ }^{1^{*}}$, Syamsuddin Toaha ${ }^{2^{*}}$, Kasbawati $^{3^{*}}$
}

\begin{abstract}
This research aims to determine the equilibrium point and analyze the stability of VSEIR model in anthrax disease with vaccination and treatment effects. It also aims to measure the sensitivity level of anthrax disease deployment to proportion vaccination effect and proportion treatment effect through the amount of $\mathcal{R}_{0}$. The research method used is a qualitative method by determining the basic reproduction number $\left(\mathcal{R}_{0}\right)$ via the next generation method to analyze the stability of non-endemic and endemic equilibrium point. The non-endemic equilibrium point is said to asymptotically stable if $\mathcal{R}_{0}<1$ and unstable if $\mathcal{R}_{0}>1$. The stability of non-endemic and endemic equilibrium points are obtained by using the Routh-Hurwitz criteria. The sensitivity analysis shows that the proportion of vaccination effects on new-born animals and treatment on infected animals can reduce the spread of anthrax virus and also eliminate endemic condition. Numerical simulations are also performed to show the effect of vaccination of new-born animals, and treatment of infected animal at anthrax disease deployment.
\end{abstract}

Keywords: Basic Reproduction Number, Equilibrium Point, Routh-Hurwitz Criteria, Vaccination, Treatment.

\begin{abstract}
Abstrak
Penelitian ini bertujuan untuk menentukan titik kesetimbangan dan menganalisis kestabilan dari model VSEIR pada penyakit antraks dengan efek vaksinasi dan pengobatan. Penelitian ini juga bertujuan untuk mengukur tingkat sensitivitas penyebaran penyakit antraks terhadap proporsi efek vaksinasi dan pengobatan melalui besaran $\mathcal{R}_{0}$. Metode penelitian yang digunakan adalah metode kualitatif dengan menentukan bilangan reproduksi dasar $\left(\mathcal{R}_{0}\right)$ yang diperoleh dari metode next generation matrix untuk menganalisis kestabilan dari titik kesetimbangan non-endemik dan endemik. Titik kesetimbangan nonendemik dikatakan stabil asimtotik lokal jika $\mathcal{R}_{0}<1$, dan tidak stabil jika $\mathcal{R}_{0}>1$. Kestabilan titik kesetimbangan non-endemik dan endemik diperoleh dengan menggunakan kriteria Routh-Hurwitz. Dari analisis sensitivitas menunjukkan bahwa proporsi efek vaksinasi hewan yang baru lahir dan pengobatan pada hewan yang telah terinfeksi dapat mengurangi penyebaran virus antraks dan juga menghilangkan kondisi endemik. Simulasi numerik dilakukan untuk menunjukkan tingkat efek vaksinasi hewan yang baru lahir, dan pengobatan hewan yang telah terinfeksi pada penyebaran penyakit antraks.
\end{abstract}

Kata kunci: Bilangan Reproduksi Dasar, Titik Kesetimbangan, Kriteria Routh-Hurwitz, Vaksinasi, Pengobatan.

\footnotetext{
* Program Studi Magister Matematika, FMIPA-UNHAS

Email: ${ }^{1}$ nurfitriafitry.nf@gmail.com, ${ }^{2}$ syamsuddint@gmail.com, ${ }^{3}$ kasbawati@gmail.com
} 


\section{Nurfitria Prawandani, Syamsuddin Toaha, Kasbawati}

\section{Pendahuluan}

Antraks adalah penyakit menular yang disebabkan oleh bakteri Bacillus anthracis. Penyakit ini menyerang hewan domestik maupun liar, terutama hewan herbivora seperti sapi, domba, kambing, dan dapat menyerang manusia (zoonosis) [1]. Pada awal tahun 1613 terjadi wabah antraks mengerikan yang menewaskan sekitar 60.000 jiwa warga Eropa, yang menjadikan antraks sebagai salah satu dari 25 penyakit yang mengakibatkan kerugian ekonomi, keresahan masyarakat, dan kematian hewan dan manusia yang tinggi sehingga perlu dilakukan tindakan kewaspadaan secara universal dengan baik berupa pemberian vaksinasi dan pengobatan [2].

Secara matematika, penyebaran penyakit menular dapat dimodelkan untuk dapat digunakan memprediksi penjangkitan penyakit ke depan. Dengan prediksi tersebut kita dapat kelakukan upaya pengendalian berupa pencegahan agar penyakit antraks dapat dieliminasi [3]. Ada beberapa penelitian terhadap model epidemik dari penyebaran penyakit antraks, diantaranya Friedman dkk. [4], meneliti tentang model penyebaran penyakit antraks pada populasi hewan menggunakan pengembangan dari model matematika deterministik epizootic antraks Hahn dan Furniss untuk mempelajari efek penularan antraks. Mushayabasa dkk. [5], membuat dan menyelesaikan suatu model penyebaran dan pengendalian antraks pada populasi hewan dengan mempelajari efek dari pengendalian bangkai terhadap bilangan reproduksi dasar $\mathcal{R}_{0}$. Saad-Roy dkk. [6], memperkenalkan model umum dinamika transmisi penyakit antraks pada populasi hewan dengan mempelajari efek dari vaksinasi dan pengendalian bangkai terhadap bilangan reproduksi dasar $\mathcal{R}_{0}$. Osman dkk. [7], melakukan analisis model kualitatif dan kuantitatif untuk menjelaskan dinamika transmisi penyakit antraks pada populas hewan dan manusia, menganalisis dan menentukan solusi steady state model, mempelajari efek dari pengendalian vaksin terhadap bilangan reproduksi dasar $\mathcal{R}_{0}$.

Secara khusus [4] mempelajari model SIAC penyebaran penyakit antraks, dengan pengendalian terhadap bangkai hewan sebagai strategi untuk mengurangi penyebaran penyakit, selanjutnya model yang terkait dengan antraks dikembangkan menjadi model SEIACP-MV dengan penambahan kelas exposed, kelas vektor [5], dan penambahan kelas vaksinasi [6]. Kemudian dikembangkan lagi menjadi model SIRV-SIR dengan menambahkan dinamika populasi manusia SIRV dan hewan SIR sebagai vektor. Namun karena hingga kini belum ditemukan adanya penularan penyakit antraks antara manusia ke manusia, dan hanya terjadi pada hewan ke manusia ([8,9]) maka manusia dianggap tidak berkontribusi terhadap penyebaran penyakit antraks.

Artikel ini membahas pengembangan penelitian sebelumnya dengan hanya fokus pada dinamika penyebaran penyakit antraks pada populasi hewan dengan menambahkan kelas vaksinasi di awal kelahiran serta pengobatan terhadap hewan yang telah terinfeksi sebagai strategi pengurangan penyebaran penyakit antraks. Model yang terhasil selanjutnya menjadi model VSEIR yang terdiri atas 5 kelas yaitu: $V=$ vaccinated, $S=$ susceptible, $E=$ exposed, $I=$ infection individuals dan $R=$ recovered. Dari model tersebut ditentukan keberadaan titik kesetimbangan non-endemik dan endemik. Analisis kestabilannya ditentukan melalui bilangan reproduksi dasar yang diperoleh dari metode next generation matrix. 


\section{Model Matematika}

Model VSEIR merupakan pengembangan dari model SEIR yang secara umum terbagi menjadi 4 kelas yaitu Susceptible $(S)$, Exposed (E), Infected (I), dan Recovered $(R)$ [10]. Model SEIR biasanya digunakan untuk menjelaskan dinamika penyakit yang memiliki masa inkubasi. Model SEIR adalah pengembangan dari SIS dan SIR. Beberapa penyebaran penyakit dimodelkan dalam bentuk SEIR, misalnya model penularan virus HIV ([11, 12]), model penularan virus rabies $([13,14])$, model penularan virus influenza [15] dan model untuk penyebaran penyakit lainnya.

Diagram skematik mengenai pembagian kompartemen model dapat dilihat dalam gambar 2.1 .

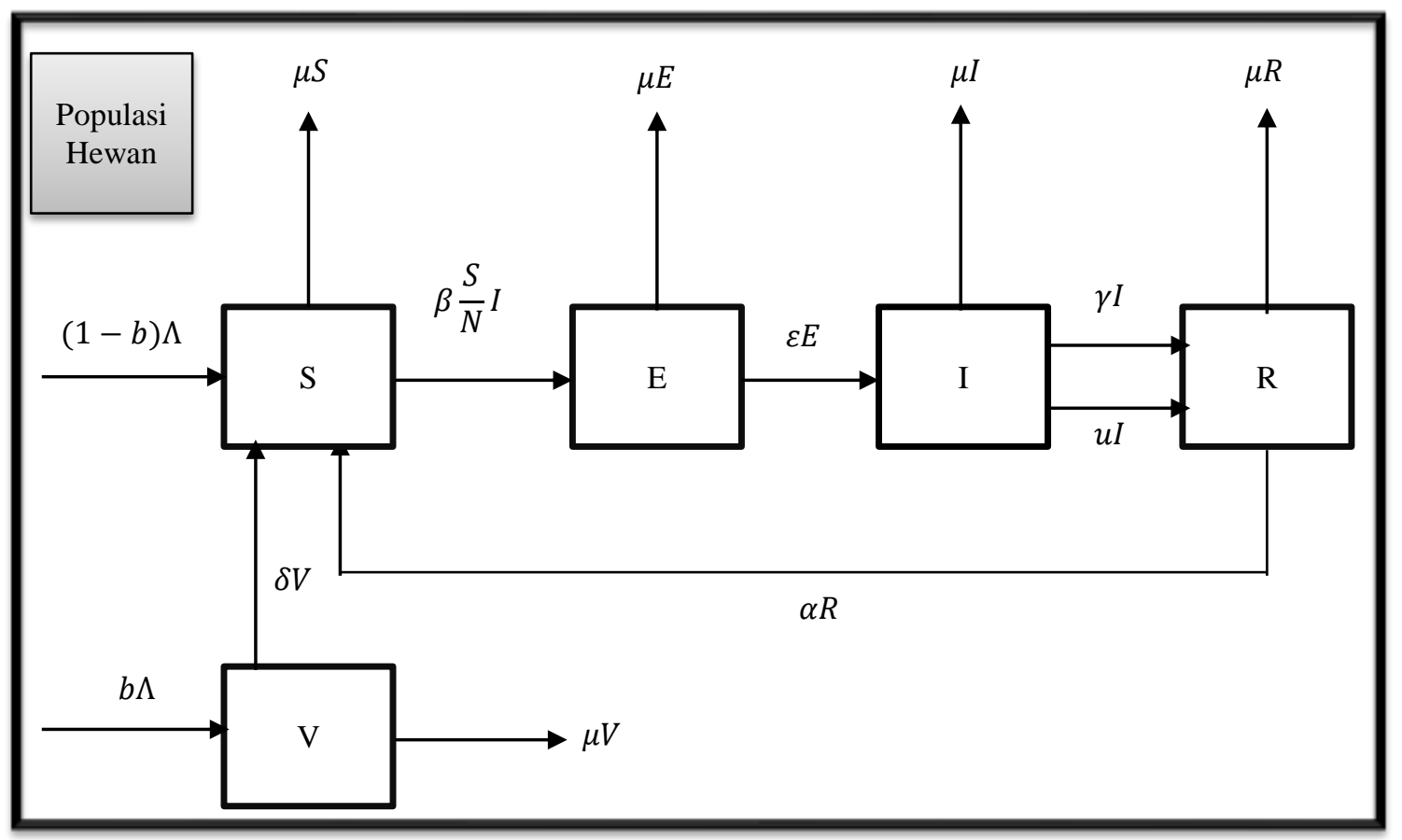

Gambar 2.1. Skema penyebaran penyakit antraks VSEIR dengan proporsi efek vaksinasi $(b)$ dan pengobatan $(u)$

Dinamika kompartemen hewan dinyatakan sebagai sistem persamaan differensial otonomi yang terdiri atas lima kompartemen hewan. Berdasarkan skema (2.1), dinamika kompartemen diberikan pada persamaan (2.1) sebagai berikut

$$
\frac{d V(t)}{d t}=b \Lambda-(\delta+\mu) V
$$




$$
\begin{aligned}
& \frac{d S(t)}{d t}=(1-b) \Lambda+\delta V+\alpha R-\beta \frac{S}{N} I-\mu S, \\
& \frac{d E(t)}{d t}=\beta \frac{S}{N} I-(\varepsilon+\mu) E, \\
& \frac{d I(t)}{d t}=\varepsilon E-(\eta+u+\mu) I, \\
& \frac{d R(t)}{d t}=\eta I+u I-(\alpha+\mu) R .
\end{aligned}
$$

Keterangan mengenai satuan dari semua variabel dan parameter model diberikan secara ringkas dalam Tabel 2.1 .

Tabel 2.1. Keterangan variabel dan parameter model VSEIR.

\begin{tabular}{clc}
\hline Variabel/Parameter & \multicolumn{1}{c}{ Deskripsi } & Nilai \\
\hline$V$ & Jumlah populasi yang diberi efek vaksinasi & - \\
$S$ & Jumlah populasi rentan antraks & - \\
$E$ & Jumlah populasi terpapar bakteri antraks & - \\
$I$ & Jumlah populasi terinfeksi bakteri antraks & - \\
$R$ & Jumlah populasi pulih sementara & - \\
$b$ & Efektivitas vaksinasi & 0.003 \\
$\mu$ & Laju kematian alami & 0.0004 \\
$\beta$ & Laju transmisi bakteri Bacillus antracis & 0.05601047 \\
$\delta$ & Tingkat berakhirnya keberhasilan vaksin & 0.004 \\
$\varepsilon$ & Laju perpindahan individu terpapar ke kelas & 0.6 \\
$\eta$ & terinfeksi & 0.0025 \\
$\alpha$ & Laju perpindahan individu terinfeksi ke & 0.07 \\
$u$ & kelas pemulihan & 0.05 \\
\hline
\end{tabular}

\section{Hasil dan Pembahasan}

Berdasarkan persamaan (2.1), jumlah populasi dinyatakan sebagai $N(t)=V(t)+S(t)+$ $E(t)+I(t)+R(t)$ yang dalam analisis ini diasumsikan bernilai konstan. Persamaan (2.1) dapat disederhanakan dengan membentuk proporsi antara banyaknya individu dalam suatu sub populasi dengan banyaknya populasi total. Misalkan $x_{1}=\frac{V(t)}{N(t)}, x_{2}=\frac{S(t)}{N(t)}, x_{3}=\frac{E(t)}{N(t)}, x_{4}=\frac{I(t)}{N(t)}, x_{6}=\frac{R(t)}{N(t)}$, yang jika disubstitusikan ke persamaan (2.1) maka diperoleh 


$$
\begin{aligned}
\frac{d x_{1}}{d t} & =b \frac{\Lambda}{N}-(\delta+\mu) x_{1}, \\
\frac{d x_{2}}{d t} & =(1-b) \frac{\Lambda}{N}+\delta x_{1}+\alpha x_{5}-\beta x_{2} x_{4}-\mu x_{2}, \\
\frac{d x_{3}}{d t} & =\beta x_{2} x_{4}-(\varepsilon+\mu) x_{3}, \\
\frac{d x_{4}}{d t} & =\varepsilon x_{3}-(\eta+u+\mu) x_{4}, \\
\frac{d x_{5}}{d t} & =\eta x_{4}+u x_{4}-(\alpha+\mu) x_{5} .
\end{aligned}
$$

Karena persamaan (3.2) adalah sistem non-linear dan analisis kestabilannya cukup rumit, maka dilakukan metode pendekatan dengan metode linearisasi di sekitar titik kesetimbangannya. Dengan demikian hanya akan diselidiki dan dianalisis perilaku titik-titik kesetimbangan secara lokal pada model. Dari persamaan (3.2) diperoleh matriks Jacobian sebagai variasi pertama yang dinyatakan sebagai

$$
J=\left[\begin{array}{ccccc}
-(\mu+\delta) & 0 & 0 & 0 & 0 \\
\delta & -\left(x_{3} \beta+\mu\right) & 0 & -\beta\left(\frac{\mu-b \mu+\delta}{\delta+\mu}\right) & \alpha \\
0 & x_{3} \beta & -(\varepsilon+\mu) & \beta\left(\frac{\mu-b \mu+\delta}{\delta+\mu}\right) & 0 \\
0 & 0 & \varepsilon & -(\eta+\mu+u) & 0 \\
0 & 0 & 0 & \eta+u & -\alpha-\mu
\end{array}\right]
$$

Titik-titik kesetimbangan non-endemik dan endemik dari persamaan (3.2) tercapai ketika semua laju kompartemen ditetapkan menjadi $0, \frac{d x_{1}}{d t}=0, \frac{d x_{2}}{d t}=0, \frac{d x_{3}}{d t}=0, \frac{d x_{4}}{d t}=0, \frac{d x_{5}}{d t}=$ 0. Dengan demikian diperoleh

$$
\begin{aligned}
b \mu-(\delta+\mu) x_{1} & =0, \\
(1-b) \mu+\delta x_{1}+\alpha x_{5}-\beta x_{2} x_{4}-\mu x_{2} & =0, \\
\beta x_{2} x_{4}-(\varepsilon+\mu) x_{3} & =0, \\
\varepsilon x_{3}-(\eta+u+\mu) x_{4} & =0, \\
\eta x_{4}+u x_{4}-(\alpha+\mu) x_{5} & =0 .
\end{aligned}
$$

Titik kesetimbangan non-endemik pada persamaan (3.2) terjadi ketika tidak ada penyebaran penyakit antraks pada populasi. Kondisi ini terpenuhi ketika $x_{3}=0$ yang kemudian diikuti oleh $x_{4}=x_{5}=0$. Substitusi $x_{3}=x_{4}=x_{5}=0$ pada persamaan (3.4), diperoleh titik kesetimbangan non-endemik 


\section{Nurfitria Prawandani, Syamsuddin Toaha, Kasbawati}

$$
\Sigma_{0}=\left(x_{1}, x_{2}, x_{3}, x_{4}, x_{5}\right)=\left(\frac{b \mu}{\delta+\mu}, \frac{\mu-b \mu+\delta}{\delta+\mu}, 0,0,0\right) .
$$

Titik kesetimbangan endemik merupakan keadaan saat penyakit menular menyebar dalam suatu populasi dan terjadi pada saat $x_{3}>0$ sehingga diperoleh $\Sigma_{1}=\left(x_{1_{1}}, x_{2_{1}}, x_{3_{1}}, x_{4_{1}}, x_{5_{1}}\right)$ di mana $\Sigma_{1} \in R_{+}^{5}$, keberadaan $\Sigma_{1} \in R_{+}^{5}$ akan dibuktikan melalui bilangan reproduksi dasar yang dijelaskan pada bagian selanjutnya.

Jika persamaan (3.2) dilinearkan di sekitar $\left(\Sigma_{0}\right)$ dan $\left(\Sigma_{1}\right)$, maka diperoleh matriks Jacobian

$$
J \Sigma_{0}=\left[\begin{array}{ccccc}
-a & 0 & 0 & 0 & 0 \\
\delta & -b & 0 & \beta\left(\frac{\mu-b \mu+\delta}{\delta+\mu}\right) & \alpha \\
0 & 0 & -c & -\beta\left(\frac{\mu-b \mu+\delta}{\delta+\mu}\right) & 0 \\
0 & 0 & \varepsilon & -d & 0 \\
0 & 0 & 0 & \eta+u & -e
\end{array}\right], J \Sigma_{1}=\left[\begin{array}{ccccc}
-f & 0 & 0 & 0 & 0 \\
\delta & -g & 0 & -\beta x_{21} & \alpha \\
0 & -\beta T_{1} & -h & \beta x_{21} & 0 \\
0 & 0 & \varepsilon & -i & 0 \\
0 & 0 & 0 & \eta+u & -j
\end{array}\right],
$$

di mana $a=(\mu+\delta), b=\mu, c=(\varepsilon+\mu), d=(\eta+\mu+u), e=(\alpha+\mu),=(\mu+\delta), g=$ $-\left(\beta x_{4_{1}}+\mu\right), h=\varepsilon+\mu, i=(\eta+\mu+u), j=(\alpha+\mu)$. Nilai karakteristik dari $J \Sigma_{0}$ merupakan akar-akar polinomial dari persamaan karakteristik $\operatorname{det}\left(J \Sigma_{0}-\lambda I\right)=0$

atau

$$
\lambda^{5}+A_{1} \lambda^{4}+A_{2} \lambda^{3}+A_{3} \lambda^{2}+A_{4} \lambda^{1}+A_{5}=0
$$

di mana $A_{1}=a+b+c+d+e, A_{2}=a b+a c+a d+a e+b c+b d+b e+c d+c e+d e+$ $r h_{1} r h_{3}, A_{3}=a b c+a b d+a b e+a c d+a c e+a d e+a r h_{1} r h_{3}+b c d+b c e+b d e+$ $b r h_{1} r h_{3}+c d e+e r h_{1} r h_{3}, A_{4}=a b c d+a b c e+a b d e+a b r h_{1} r h_{3}+a c d e+a e r h_{1} r h_{3}+$ bcde + berh $_{1} r h_{3}, A_{5}=a b c d e+$ aberh $_{1} r h_{3}$, dan $r h_{1}=\varepsilon ; r h_{2}=\delta ; r h_{3}=\beta x_{2_{0}} ; r h_{4}=$ $\alpha ; r h_{5}=\eta+u$.

Solusi persamaan karakteristik (3.6) sulit didapatkan secara eksplisit karena melibatkan banyak parameter di dalamnya. Salah satu cara yang dapat digunakan untuk mengetahui jenis akar polinomial (3.2) yaitu dengan menerapkan uji kestabilan Routh-Hurwitz, di mana polinomial (3.2) memiliki akar-akar dengan bagian real yang negatif jika memenuhi syarat-syarat berikut, $([16,17,18])$.

(R1) $H_{1}=A_{1}>0$,

$$
H_{2}=\left|\begin{array}{cc}
A_{1} & 0 \\
1 & A_{2}
\end{array}\right|>0 . A_{1}, A_{2}>0 \operatorname{dan} A_{1} A_{2}>0
$$


(R3)

$$
\begin{aligned}
& H_{3}=\left|\begin{array}{ccc}
A_{1} & A_{3} & 0 \\
1 & A_{2} & 0 \\
0 & A_{1} & A_{3}
\end{array}\right| A_{1}, A_{2}, A_{3}>0 \operatorname{dan} A_{1} A_{2} A_{3}-A_{3}^{2}>0 \\
& H_{4}=\left|\begin{array}{cccc}
A_{1} & A_{3} & 0 & 0 \\
1 & A_{2} & A_{4} & 0 \\
0 & A_{1} & A_{3} & 0 \\
0 & 1 & A_{2} & A_{4}
\end{array}\right|>0 A_{1}, A_{2}, A_{3}, A_{4}>0 \text { dan } A_{1} A_{2} A_{3} A_{4}-A_{1}^{2} A_{4}^{2}-A_{3}^{2} A_{4}>0 \\
& H_{5}=\left|\begin{array}{ccccc}
A_{1} & A_{3} & A_{5} & 0 & 0 \\
1 & A_{2} & A_{4} & 0 & 0 \\
0 & A_{1} & A_{3} & A_{5} & 0 \\
0 & 1 & A_{2} & A_{4} & 0 \\
0 & 0 & A_{1} & A_{3} & A_{5}
\end{array}\right|>0 A_{1}, A_{2}, A_{3}, A_{4}, A_{5}>0 \text { dan } A_{1} A_{2} A_{3} A_{4} A_{5}- \\
& A_{1}^{2} A_{2}^{2} A_{5}^{2}-A_{1}^{2} A_{4}^{2} A_{5}+2 A_{1} A_{4} A_{5}^{2}-A_{3}^{2} A_{4} A_{5}+A_{3} A_{2} A_{5}^{2}-A_{5}^{3}>0
\end{aligned}
$$

Suatu model biasanya memiliki parameter threshold yang dikenal sebagai bilangan reproduksi dasar $\left(\mathcal{R}_{0}\right)$, sedemikian sehingga jika $\mathcal{R}_{0}<1$ maka titik kesetimbangan non-endemik stabil asimtotik lokal dan penyakit tidak menyerang populasi, namun jika $\mathcal{R}_{0}>1$ maka titik kesetimbangan non-endemik tidak stabil dan penyakit sangat mungkin untuk menyebar [19]. Bilangan $\mathcal{R}_{0}$ diperoleh dengan memisalkan $\mathcal{F}_{i}(x)$ sebagai laju penambahan infeksi baru pada kompartemen $i$ dan $\mathcal{V}_{i}(x)$ adalah laju perpindahan individu pada kompartemen $i$, maka $\mathcal{F}_{i}(x)$ dan $\mathcal{V}_{i}(x)$ dari persamaan (3.2) adalah sebagai berikut

$$
\begin{aligned}
& \mathcal{F}(x)=\left(\begin{array}{c}
\beta x_{2} x_{4} \\
0 \\
0
\end{array}\right), \\
& \mathcal{V}(x)=\left(\begin{array}{c}
\left.(\varepsilon+\mu) x_{3}\right) \\
-\varepsilon x_{3}+(\eta+u+\mu) x_{4} \\
-(\eta+u) x_{4}+(\alpha+\mu) x_{5}
\end{array}\right) .
\end{aligned}
$$

Dari persamaan (3.7) dan (3.8) diperoleh matriks $F$ dan $V$ sebagai berikut

$$
F=\frac{\partial \mathcal{F}_{i}\left(\Sigma_{0}\right)}{\partial x_{j}}=\left(\begin{array}{lll}
\frac{\partial F_{1}}{\partial x_{3}} & \frac{\partial F_{1}}{\partial x_{4}} & \frac{\partial F_{1}}{\partial x_{5}} \\
\frac{\partial F_{2}}{\partial x_{3}} & \frac{\partial F_{2}}{\partial x_{4}} & \frac{\partial F_{2}}{\partial x_{5}} \\
\frac{\partial F_{3}}{\partial x_{3}} & \frac{\partial F_{3}}{\partial x_{4}} & \frac{\partial F_{3}}{\partial x_{5}}
\end{array}\right)=\left(\begin{array}{ccc}
0 & \beta x_{2} & 0 \\
0 & 0 & 0 \\
0 & 0 & 0
\end{array}\right),
$$




$$
V=\frac{\partial \mathcal{V}_{i}\left(\Sigma_{0}\right)}{\partial x_{j}}=\left(\begin{array}{ccc}
C_{1} & 0 & 0 \\
-\varepsilon & C_{2} & 0 \\
0 & -(\eta+u) & C_{3}
\end{array}\right)
$$

dengan $C_{1}=\varepsilon+\mu, C_{2}=\eta+u+\mu, C_{3}=\alpha+\mu$. Invers dari matriks $V$ adalah

$$
V^{-1}(x)=\left(\begin{array}{ccc}
\frac{1}{C_{1}} & 0 & 0 \\
\frac{\varepsilon}{C_{1} C_{2}} & \frac{1}{C_{2}} & 0 \\
\frac{\varepsilon(\eta+u)}{C_{1} C_{2} C_{3}} & \frac{\eta+u}{C_{2} C_{3}} & \frac{1}{C_{3}}
\end{array}\right)
$$

Nilai bilangan reproduksi dasar dari persamaan (3.2) dapat ditentukan melalui matriks $F$ dan $V^{-1}$ tersebut. Dari persamaan (3.9) dan (3.11) diperoleh

$$
F V^{-1}=\left(\begin{array}{ccc}
0 & \beta x_{2} & 0 \\
0 & 0 & 0 \\
0 & 0 & 0
\end{array}\right)\left(\begin{array}{ccc}
\frac{1}{C_{1}} & 0 & 0 \\
\frac{\varepsilon}{C_{1} C_{2}} & \frac{1}{C_{2}} & 0 \\
\frac{\varepsilon(\eta+u)}{C_{1} C_{2} C_{3}} & \frac{\eta+u}{C_{2} C_{3}} & \frac{1}{C_{3}}
\end{array}\right)=\left(\begin{array}{ccc}
\frac{\beta x_{2} \varepsilon}{C_{1} C_{2}} & \frac{\beta x_{2}}{C_{2}} & 0 \\
0 & 0 & 0 \\
0 & 0 & 0
\end{array}\right)
$$

Selanjutnya nilai eigen dari matriks $F V^{-1}$ diperoleh dengan menyelesaikan persamaan berikut

$$
\operatorname{det}\left(F(x) V^{-1}(x)-\lambda I\right)=\left(\begin{array}{ccc}
\frac{\beta x_{2} \varepsilon}{C_{1} c_{2}}-\lambda & \frac{\beta x_{2}}{C_{2}} & 0 \\
0 & -\lambda & 0 \\
0 & 0 & -\lambda
\end{array}\right)=0 .
$$

Dengan menyelesaikan persamaan $\operatorname{det}\left(F(x) V^{-1}(\mathrm{x})-\lambda I\right)=0$, maka diperoleh persamaan karakteristik $\left(\frac{\beta x_{2} \varepsilon}{C_{1} C_{2}}-\lambda\right) \lambda^{2}=0$. Akar-akar dari persamaan karakteristik tersebut adalah $\lambda_{1}=$ $\frac{\beta x_{2} \varepsilon}{C_{1} C_{2}}$, dan $\lambda_{2,3}=0$. Berdasarkan akar-akar tersebut diperoleh radius spektral dari matriks next generation $F V^{-1}$ yaitu $\lambda_{\max }=\frac{\beta x_{2} \varepsilon}{C_{1} C_{2}}$, selanjutnya $\lambda_{\max }$ tersebut disebut sebagai $\mathcal{R}_{0}=\frac{\beta x_{2} \varepsilon}{C_{1} C_{2}}$,jika nilai $C_{1}, C_{2}, C_{3}$ dan $x_{2}$ yang merupakan komponen dari titik kesetimbangan $\Sigma_{0}$ disubstitusi ke $\mathcal{R}_{0}=\frac{\beta x_{2} \varepsilon}{C_{1} C_{2}}$ diperoleh

$$
\mathcal{R}_{0}=\frac{\beta(\mu(1-b)+\delta) \varepsilon}{(\delta+\mu)(\varepsilon+\mu)(\gamma+u+\mu)}
$$

Nilai bilangan reproduksi dasar $\mathcal{R}_{0}$ menentukan keberadaan titik kesetimbangan endemik maupun non-endemik. Nilai dari persamaan (3.13) tergantung pada beberapa nilai dari parameter persamaan (3.2). Oleh karena itu, tidak semua parameter dari persamaan (3.2) dapat dikontrol agar menekan bilangan reproduksi dasar kurang dari 1, untuk membuat titik kesetimbangan nonendemik stabil, maka difokuskan pada parameter yang terkait dengan upaya pencegahan meningkatnya jumlah populasi yang terinfeksi penyakit antraks yaitu parameter hewan baru lahir 


\section{Nurfitria Prawandani, Syamsuddin Toaha, Kasbawati}

yang divaksinasi $(b \mu)$ dan proporsi individu terinfeksi yang pindah ke kelas pemulihan dengan pengobatan $(u)$.

Adapun proporsi efek vaksinasi pada hewan dapat dilihat melalui turunan $\mathcal{R}_{0}$ terhadap $b \mu$ yaitu

$$
\frac{\partial \mathcal{R}_{0}}{\partial b \mu}=\left(-\frac{\beta \varepsilon(1)}{(\delta+\mu) c_{1} c_{2}}\right)\left(\frac{b \mu c_{1} c_{2}(\delta+\mu)}{\beta((1-b) \mu+\delta) \varepsilon}\right)=-\frac{b \mu}{\mu(1-b)+\delta}<0,
$$

dan efek pemberian obat dapat dilihat melalui $\mathcal{R}_{0}$ terhadap $u$ yaitu

$$
\frac{\partial \mathcal{R}_{0}}{\partial u}=\left(-\frac{\beta \varepsilon(-b \mu+\mu+\delta)(1)}{(\delta+\mu)(\varepsilon+\mu)(\eta+u+\mu)^{2}}\right)\left(\frac{u(\delta+\mu)(\varepsilon+\mu)(\eta+u+\mu)}{\beta \varepsilon(-b \mu+\mu+\delta)}\right)=-\frac{u}{\eta+u+\mu}<0 .
$$

Hasil yang diperoleh dari bentuk $\frac{\partial \mathcal{R}_{0}}{\partial b \mu}<0$ dan $\frac{\partial \mathcal{R}_{0}}{\partial u}<0$ menunjukkan bahwa semakin besar proporsi efek vaksinasi dan pengobatan pada populasi hewan maka $\mathcal{R}_{0}$ akan semakin kecil sehingga titik kesetimbangan non-endemik stabil dan wilayah bebas dari penyakit.

Pada bagian ini simulasi dilakukan untuk menunjukkan proporsi efek vaksinasi terhadap populasi hewan. Dalam hal ini akan ditunjukkan bahwa peningkatan atau penurunan nilai parameter $b$ dapat mengubah bilangan reproduksi dasar $\left(\mathcal{R}_{0}\right)$. Adapun perubahannya dapat dilihat pada Tabel 3.2.

\begin{tabular}{|c|c|c|c|}
\hline Parameter $b$ & $\mathcal{R}_{0}$ & $\begin{array}{c}\text { Kestabilan titik kesetimbangan } \Sigma_{0} \\
\text { dan nilai eigen } \lambda_{4} \text { dan } \lambda_{5}\end{array}$ & $\begin{array}{c}\text { Kestabilan titik kesetimbangan } \\
\Sigma_{1} \text { dan nilai eigen } \lambda_{2} \text { dan } \lambda_{3}\end{array}$ \\
\hline 0.5 & 1.0099 & $\begin{array}{c}\lambda_{4}=\mathbf{0 . 0 0 0 4}, \lambda_{5}=-0.0044 \\
\Sigma_{0} \text { tidak stabil }\end{array}$ & $\begin{array}{c}\lambda_{2}=-0.0004, \lambda_{3}=-0.0004 \\
\Sigma_{1} \text { stabil }\end{array}$ \\
\hline 0.55 & 1.0003 & $\begin{array}{c}\lambda_{4}=\mathbf{0 . 0 0 0 2}, \lambda_{5}=-0.0044 \\
\Sigma_{0} \text { tidak stabil }\end{array}$ & $\begin{array}{c}\lambda_{2}=-0.0003, \lambda_{3}=-0.0002, \\
\Sigma_{1} \text { stabil }\end{array}$ \\
\hline 0.61 & 0.9994 & $\begin{array}{c}\lambda_{4}=-0.00002, \lambda_{5}=-0.0044 \\
\Sigma_{0} \text { stabil }\end{array}$ & $\begin{array}{c}\lambda_{2}=-0.0004, \lambda_{3}=\mathbf{0 . 0 0 0 0 2}, \\
\Sigma_{1} \text { tidak stabil }\end{array}$ \\
\hline 0.7 & 0.9907 & $\begin{array}{c}\lambda_{4}=-0.0004, \lambda_{5}=-0.0044, \\
\Sigma_{0} \text { stabil }\end{array}$ & $\begin{array}{c}\lambda_{2}=\mathbf{0 . 0 0 0 4}, \lambda_{3}=-0.0003, \\
\Sigma_{1} \text { tidak stabil }\end{array}$ \\
\hline
\end{tabular}

Tabel 3.2. Proporsi efek vaksinasi $(b)$ pada hewan terhadap bilangan reproduksi dasar $\mathcal{R}_{0}$

Pada Tabel 3.2 terlihat bahwa semakin besar nilai proporsi efek vaksinasi $b$ maka nilai bilangan reproduksi dasar $\mathcal{R}_{0}$ semakin kecil. Untuk nilai proporsi efek vaksinasi sebesar 0.55 , nilai $\mathcal{R}_{0}>1$ dan salah satu nilai eigen dari matriks Jacobi $\Sigma_{0}$ yaitu $\lambda_{4}$ bernilai positif dan nilai eigen dari matriks Jacobi $\Sigma_{1}$ bernilai negatif, berdasarkan syarat uji kestabilan Routh-Hurwitz (R1-R5), titik kesetimbangan non-endemik tidak stabil dan titik kesetimbangan endemik stabil. Karena keadaan yang diinginkan adalah pada saat yang stabil adalah titik kesetimbangan nonendemik agar wilayah bebas dari penyakit, maka proporsi efek vaksinasi ditingkatkan. Pada Tabel 3.2 dapat dilihat bahwa pada saat parameter ditingkatkan menjadi 0.61 , nilai $\mathcal{R}_{0}<1$ dan semua 


\section{Nurfitria Prawandani, Syamsuddin Toaha, Kasbawati}

nilai eigen dari matriks Jacobi $\Sigma_{0}$ bernilai negatif, berdasarkan (R1-R5) maka titik kesetimbangan non-endemik stabil asimtotik lokal dan wilayah bebas dari penyakit. Berdasarkan uji kestabilan Routh-Hurwitz nilai $\mathcal{R}_{0}<1$ menunjukkan kestabilan dari titik kesetimbangan non-endemik $\Sigma_{0}$.

Tabel 3.3. Proporsi efek pengobatan $(u)$ pada hewan terhadap bilangan reproduksi dasar $\mathcal{R}_{0}$

\begin{tabular}{|c|c|c|c|}
\hline Parameter $u$ & $\mathcal{R}_{0}$ & $\begin{array}{l}\text { Kestabilan titik kesetimbangan } \Sigma_{0} \\
\text { dan nilai eigen } \lambda_{4} \text { dan } \lambda_{5}\end{array}$ & $\begin{array}{c}\text { Kestabilan titik kesetimbangan } \\
\Sigma_{1} \text { dan nilai eigen } \lambda_{2} \text { dan } \lambda_{3}\end{array}$ \\
\hline 0.05 & 1.0484 & $\begin{array}{c}\lambda_{4}=\mathbf{0 . 0 0 2 3}, \lambda_{5}=-0.0044 \\
\Sigma_{0} \text { tidak stabil }\end{array}$ & $\begin{array}{c}\lambda_{2}=-0.0023, \lambda_{3}=-0.0004, \\
\Sigma_{1} \text { stabil }\end{array}$ \\
\hline 0.052 & 1.0102 & $\begin{array}{c}\lambda_{4}=\mathbf{0 . 0 0 0 5}, \lambda_{5}=-0.0044 \\
\Sigma_{0} \text { tidak stabil }\end{array}$ & $\begin{array}{c}\lambda_{2}=-0.0005, \lambda_{3}=-0.0003, \\
\Sigma_{1} \text { stabil }\end{array}$ \\
\hline 0.053 & 0.9922 & $\begin{array}{c}\lambda_{4}=-0.0003, \lambda_{5}=-0.0044 \\
\Sigma_{0} \text { stabil }\end{array}$ & $\begin{array}{c}\lambda_{2}=-0.0004, \lambda_{3}=\mathbf{0 . 0 0 0 3} \\
\Sigma_{1} \text { tidak stabil }\end{array}$ \\
\hline 0.07 & 0.7608 & $\begin{array}{c}\lambda_{4}=-0.0159, \lambda_{5}=-0.0044 \\
\Sigma_{0} \text { stabil }\end{array}$ & $\begin{array}{c}\lambda_{2}=\mathbf{0 . 0 1 4 1}, \lambda_{3}=-0.6724, \\
\Sigma_{1} \text { tidak stabil }\end{array}$ \\
\hline
\end{tabular}

Pada Tabel 3.3 terlihat bahwa semakin besar nilai proporsi efek pengobatan $u$ maka nilai bilangan reproduksi dasar $\mathcal{R}_{0}$ semakin kecil. Nilai $\mathcal{R}_{0}<1$ pada saat parameter $u=0.053$, yang artinya titik kesetimbangan $\Sigma_{0}$ stabil asimtotik lokal pada saat $u \geq 0.053$. Untuk lebih jelas, akan diberikan grafik hubungan antara $b$ dan $u$ pada saat $\mathcal{R}_{0}=1$ yang disajikan pada gambar 3.2.

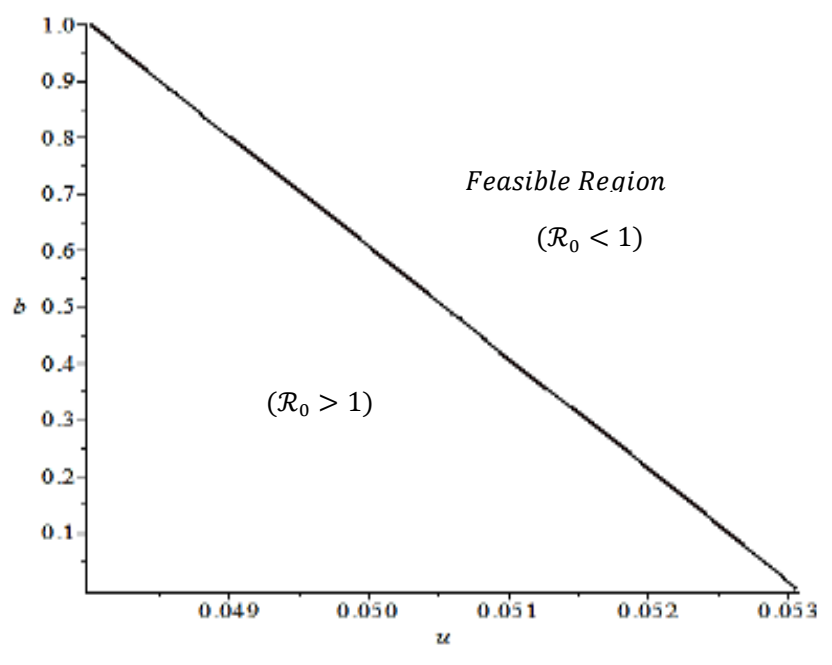

Gambar 3.2. Hubungan antara $b$ dan $u$ ketika $\mathcal{R}_{0}=1$.

Pada gambar 3.2 terlihat bahwa keadaan non-endemik dapat diperoleh dengan pemberian $u \geq 0.053$ dan $b=0$. Untuk keadaan non-endemik dengan parameter $u<0.053$, maka parameter $b$ harus lebih besar dari 0 . 


\section{Nurfitria Prawandani, Syamsuddin Toaha, Kasbawati}

\section{Kesimpulan}

Analisis model matematika VSEIR pada penyebaran penyakit antraks dengan proporsi efek vaksinasi dan pengobatan menghasilkan dua titik, yaitu titik kesetimbangan non-endemik $\left(\Sigma_{0}\right)$ dan endemik $\left(\Sigma_{1}\right)$. Titik kesetimbangan non-endemik $\left(\Sigma_{0}\right)$ stabil asimtotik lokal jika nilai $\mathcal{R}_{0}<1$ dan tidak stabil jika $\mathcal{R}_{0}>1$. Berdasarkan nilai bilangan reproduksi dasar $\left(\mathcal{R}_{0}\right)$, diperoleh beberapa parameter yang berpengaruh, yaitu proporsi efek vaksinasi pada hewan baru lahir $(b)$, dan proporsi efek pengobatan pada hewan yang telah terinfeksi $(u)$. Berdasarkan simulasi numerik, proporsi efek vaksinasi dan pengobatan memiliki pengaruh terhadap perubahan $\mathcal{R}_{0}$. Jika parameter $b$ dan $u$ yang diberikan rendah, maka $\mathcal{R}_{0}>1$ yang artinya kondisi endemik masih terjadi, jika $b$ dan $u$ semakin diperbesar maka nilai $\mathcal{R}_{0}$ semakin kecil dan kondisi menjadi nonendemik. Namun dari kedua penanganan tersebut, pengobatan adalah cara paling efektif, di mana perubahan keadaan dari endemik ke non-endemik dapat terjadi hanya dengan pemberian parameter $u \geq 0.053$ dan $b=0$. Hal ini menunjukkan bahwa, cara terbaik yang dapat dilakukan adalah dengan meningkatkan proporsi efek pengobatan karena pengaruhnya yang signifikan terhadap penurunan penyebaran penyakit antraks, walaupun tanpa proporsi efek vaksinasi.

\section{Daftar Pustaka}

[1] OFFICE INTERNATIONAL DES EPIZOOTIES, (OIE). (2000). Anthrax. In: Manual of Standards Diagnostic and Vaccines. World Health Organization. pp. 235-239.

[2] World Health Organization. (2008). Anthrax in humans and animals - 4th ed., 30(3), 299300. https://doi.org/10.2105/ajph.30.3.299.

[3] Fred, B., \& Charlos-Charez, C. (2000). Mathematical Models in Population Biology and Epidemiology. New York: Springer.

[4] Friedman, A., \& Yakubu, A.-A. (2013). Anthrax epizootic and migration: Persistence or extinction. Mathematical Biosciences. https://doi.org/10.1016/j.mbs.2012.10.004.

[5] Mushayabasa, S., Marijani, T., \& Masocha, M. (2017). Dynamical analysis and control strategies in modeling anthrax. Computational and Applied Mathematics. https://doi.org/10.1007/s40314-015-0297-1.

[6] Saad-Roy, C.M., van den Driessche, P., \& Yakubu, A.A. (2017). A Mathematical Model of Anthrax Transmission in Animal Populations. Bulletin of Mathematical Biology, 79(2), 303-324. https://doi.org/10.1007/s11538-016-0238-1.

[7] Osman, S., \& Makinde, O.D. (2018). Mathematical Modelling of the Transmission Dynamics of Anthrax in Human and Animal Population. Mathematics Theory and Modeling. Vol. 8, No. 6.

[8] Gombe, N.T., Nkomo, B.M.M., Chadambuka, A., Shambira, G., \& Tshimanga, M. (2010). Risk factors for contracting anthrax in Kuwirirana ward, Gokwe North, Zimbabwe. African Health Sciences. Vol. 10, No. 2, hal. 159-64. 


\section{Nurfitria Prawandani, Syamsuddin Toaha, Kasbawati}

[9] CDC. (2017). Anthrax. Centers for Diseases Control and Prevention. https://www.cdc.gov/anthrax/index.html, [15 Agustus 2019].

[10] Zhang, J., Jia, J., \& Song, X. (2014). Analysis of an SEIR Epidemic Model with Saturated Incidence and Saturated Treatment Function. The Scientific World Journal, 2014, 1-11. doi:10.1155/2014/910421.

[11] Sun, C., \& Hsieh, Y.H. (2010). Global analysis of an SEIR model with varying population size and vaccination. Applied Mathematical Modelling, Vol. 34, No. 10, hal. 2685-2697.

[12] Li, J., \& Cui, N. (2013). Dynamic Analysis of an SEIR Model with Distinct Incidence for Exposed and Infectives. The Scientific World Journal, 2013, 5. doi:10.1155/2013/871393.

[13] Ruan, S. (2017). Modeling the transmission dynamics and control of rabies in China. Mathematical Biosciences, 286, 65-93. doi:10.1016/j.mbs.2017.02.005.

[14] Wiraningsih, E.D., Agusto, F., Aryati, L., Lenhart, S., Toaha, S., Widodo, \& Govaerts W. (2015). Stability analysis of rabies model with vaccination effect and culling in dogs. Applied Mathematical Sciences, Vol. 9, No. 77, hal. 3805-3817.

[15] Etbaigha, F., Willems, A.R., \& Poljak, Z. (2018). An SEIR model of influenza a virus infection and reinfection within a farrow-to-finish swine farm PLOS ONE 13(9) e0202493. https://doi.org/10.1371/journal.pone.0202493.

[16] Murray, J.D. (2002), Mathematical Biology I: An Introduction, Third Edition. Springer: New York, USA.

[17] Willems, J.L. (1970). Stability theory of dynamical system. London: Thomas Nelson \& Sons.

[18] Toaha, S. (2013). Pemodelan Matematika dalam Dinamika Populasi. Makassar: Dua Satu Press.

[19] Van den Driessche, P., \& Watmough, J. (2002). Reproduction numbers and sub-threshold endemic equilibria for compartmental models of disease transmission. Mathematical Biosciences. https://doi.org/10.1016/S0025-5564(02)00108-6. 